\title{
PENGARUH PENGETAHUAN WAJIB PAJAK, KESADARAN WAJIB PAJAK, SANKSI PAJAK KENDARAAN BERMOTOR DAN SISTEM SAMSAT DRIVE THRU TERHADAP KEPATUHAN WAJIB PAJAK KENDARAAN BERMOTOR
}

\author{
ANIS SYAMSU RIZAL \\ Prodi $S 1$ Akuntansi Universitas Pamulang \\ *Email :dosen01955@unpam.ac.id
}

\begin{abstract}
This study aims to examine the influence of knowledge of taxpayers, taxpayer awareness, motor vehicle tax sanctions, and samsat drive thru system of tax compliance on motor vehicles in samsat south jakarta. The data that is this study are "primary data from the results of questionnaires. respondents in the system samsat drive thru". The questionnaire was distributed to 125 respondents and data that can be processed are 100 questionnaires. the sampling method used accidental sampling. The data analysis techniques in this study used "multiple linear regression techniques".The result of regression analysis shows that "the knowledge of taxpayers, taxpayer awareness and samsat drive thru system have a positive effect on motor vehicle tax compliance while motor vehicle tax sanction has no significant effect on vehicle tax compliance".
\end{abstract}

Keywords: knowledge of taxpayers, taxpayer awareness, motor vehicle tax sanctions, and drive thru samsat system, vehicle tax compliance.

\section{PENDAHULUAN}

Pada saat ini, jumlah pemilik kendaraan bermotor terus bertambah, sudah seharusnya kantor samsat memanfaatkan dengan baik untuk menjadi motor penggerak dalam pemungutan pajak untuk pajak kendaraan bermotor di seluruh Wilayah di Indonesia, hal tersebut dilakukan guna meningkatkan Pendapatan Asli Daerah (PAD) melalui peningkatan akan kepatuhan para wajib pajak yang berarti pemasukan negara juga terus bertambah.

Kebutuhan akan alat transportasi di zaman sekarang snagat menjadi skala prioritas bagi masyarakat, karena memudahkan perjalanan ke tempat yang dituju dengan waktu cepat. Kendaraan bermotor bukan lagi menjadi brang mewah untuk masyarakat Indonesia saat ini, karena di tiap rumah sudah ada bahkan kadang lebih dari 1 yang dimiliki. Peningkatan daya beli masyarakat akan kendaraan bermotor menjadi kebutuhan pokok karena transportasi umum kadang tidak tepat waktu dan kondisinya sudah kurang layak. Semakin meningkat jumlah kendaraan yang ada, maka terjadi peningakatan Wajib Pajak Kendaraan Bermotor tiap 
tahunnya. Dampaknya akan sangat dirasakan oleh pemerintah daerah, karena dengan jumlah yang relatif meningkat terus, maka akan berimbas pada meningkatnya penerimaan pajak. Dari hal tersebut harusnya pemerintah daerah menerima banyak masukkan dari sektor pajak kendaraan bermotor, tapi karena tidak sedikitnya penunggakan yang dilakukan maka belum maksimal penerimaan pajak yang diperoleh, ada beberapa alasan penunggakan pembayaran pajak oleh pemilik kendaraan bermotor, beberapa alasan di antaranya adalah kepatuhan dan kesadaran Wajib Pajak. Data penunggakan di peroleh dari Kepala BPRD Jakarta melalui MetroTvnews.com sebagai berikut:

Tabel 1.1 Data Penunggakan WP PKB Samsat Jakarta Selatan

\begin{tabular}{|l|l|l|}
\hline Tahun & Jumlah WP PKB & WP yang Menunggak \\
\hline 2014 & 901.133 & 8 \\
\hline 2015 & 931.428 & 3 \\
\hline 2016 & 958.721 & 5 \\
\hline 2017 & 976.900 & 17 \\
\hline
\end{tabular}

Sumber: Kepala BPRD, Bapak Edi Sumantri.

Kondisi Tahun 2014 pada Tabel 1.1 terlihat adanya penunggakan akan kewajiban atas pajak kendaraan bermotor di Jakarta Selatan yaitu 8 wajib pajak kendaraan bermotor, sedangkan pada tahun 2015 seperti pada tabel di atas, ada 3 wajib pajak yang menunggak, selanjutnya di tahun 2016 pada tabel di atas menunjukkan adanya 5 penunggak, data terakhir di tahun 2017 ada 17 penunggak yang menjadi tolak ukur bahwa sangat signifikan sekali kenaikan jumlah penunggak pajak kendaraan bermotor. Dari data pada tabel 1.1, perlu adanya tindakan aplikatif yang dilakukan oleh elemen terkait dalam meningkatkan penerimaan pajak pada penerimaan pajak kendaraan bermotor.

Kepala Unit PKB Jakarta Selatan, Khairul Anwar, mengatakan wilayahnya masuk dalam daftar daerah dengan hutang pajak kendaraan terbesar di Jakarta. Dari seluruhnya ada 20 persen yang belum bayar PKB (Pajak Kendaraan Bermotor), "Kata Khairil, di Jalan Raya Kalibata, Jakarta Selatan pada Selasa (24/4/2018).

"Kepatuhan Perpajakan merupakan tindakan wajib pajak dalam memenuhi kewajiban akan perpajakannya sesuai dengan ketentuan peraturan perundangundangan dan peraturan pelaksanaan perpajakan yang berlaku dalam suatu negara" (Siti Kurnia Rahayu, 2010:112).

Zain (2008: 78) berpendapat bahwa sanksi pajak adalah "jaminan ketentuan peraturan perundang-undangan perpajakan (norma perpajakan) akan dituruti/dipatuhi", dapat didefinisikan bahwa "sanksi perpajakan merupakan alat pencegah agar wajib pajak tidak melanggar norma perpajakan". Dengan adanya sanksi atas pajak yang tidak tertib, diharapkan ketaatan masyarakat akan pembayaran pajak berjalan dengan baik sesuai ketentuan yang telah disosialisasikan kepada masyarakat.

Drive thru yang ada pada unit pelayanan "SAMSAT" saat ini adalah "salah satu terobosan dalam upaya meningkatkan mutu pelayanan terhadap para wajib 
pajak". Masyarakat diharapkan tidak "kesulitan mengantri di depan loket", Pajak Kendaraan Bermotor menjadi lebih mudah dibayarkan.

Hasil penelitian terdahulu dilakukan oleh Ilhamsyah dkk., (2016), dengan judul "pengaruh pemahaman dan pengetahuan wajib pajak tentang peraturan perpajakan, kesadaran wajib pajak, kualitas pelayanan, dan sanksi perpajakan terhadap kepatuhan wajib pajak kendaraan bermotor". Sistem Samsat drive thru menjadi variabel independen yang membedakan dengan penelitian sebelumnya, diteliti lebih dahulu oleh Wardani dan Rumiyatun (2017).

\section{LANDASAN TEORI DAN PENGEMBANGAN HIPOTESIS}

\section{Landasan Teori}

Teori Atribusi

Teori atribusi sangat relevan untuk menerangkan bahwa "kepatuhan Wajib Pajak berkaitan erat dengan sikap Wajib Pajak dalam membuat penilaian terhadap pajak itu sendiri". Persepsi seseorang menilai orang lain dapat dipengaruhi oleh faktor internal ataupun eksternal. "Teori atribusi pada dasarnya menyatakan bahwa bila individu-individu mengamati perilaku orang lain maka mereka mencoba untuk menentukan apakah prilaku itu ditimbulkan karena pengaruh internal atau eksternal", (Lubis, 2010: 97).

\section{Teori Prospek}

Teori propek bertujuan untuk "menggambarkan konsumen membuat keputusan jika terdapat kondisi ketidakpastian pada konsekuensi pilihannya" (Diana Sari, 2013:33) Teori prospek membedakan 2 fase proses pemilihan : fase editing dan fase evaluasi.

\section{Pengertian Pajak}

Pajak dari pernyataan Waluyo (2009: 2) yaitu "iuran masyarakat kepada Negara (yang dipaksakan) yang terutang oleh yang wajib membayarnya menurut peraturan-peraturan umum (undang-undang) dengan tidak mendapat prestasi kembali yang langsung dapat ditunjuk dan yang gunanya adalah untuk membiayai pengeluaran-pengeluaran umum berhubung tugas Negara untuk menyelenggarakan pemerintahan". Pernyataan tersebut sepertinya sesuai dengan kondisi di masyarakat, bahwa pajak merupakan bagian dari paksaan yang dilakukan oleh pemerintah dan nantinya phasilnya akan digunakan oleh pemerintah itu sendiri.

\section{Pengetahuan Wajib Pajak}

Rahayu (2010: 112) menyatakan bahwa "kualitas pengetahuan yang semakin baik akan memberikan sikap memenuhi kewajiban dengan benar melalui adanya sistem perpajakan suatu negara yang dianggap adil". Dari pemahaman yang dimiliki oleh wajib pajak tersebut memberikan dampak pada wajib pajak, bahwa pajak yang dibayarkan merupakan "wujud gotong royong nasional untuk menghimpun dana yang selanjutnya akan digunakan untuk kepentingan 
pembiayaan pemerintah dan pembangunan nasional yang wujud nyatanya dapat dinikmati oleh masyarakat selaku wajib pajak itu sendiri”.

\section{Kesadaran Wajib Pajak}

Kesadaran perpajakan yang dikemukan oleh Irianto (2005: 36) bahwa "kesadaran membayar pajak tidak tumbuh dengan baik di masyarakat disebabkan adanya perbedaan kepentingan, kepentingan dari wajib pajak dengan dengan kepentingan pemerintah dalam pelaksanaan perpajakan". Dari pendapat tersebut, kesadaran perpajakan pada masyarakat belum tumbuh dengan baik, yang memungkinkan ada variabel lain yang menyebabkan hal tersebut.

\section{Sanksi Pajak Kendaraan Bermotor}

Zuraida (2012: 33-39) menyatakan, "Pajak kendaraan bermotor adalah bagian pajak daerah yang termasuk ke dalam jenis pajak provinsi”. Sanksi tegas yang diterapkan, diharapkan akan membuat wajib pajak melaporkan semua pendapatan yang diperolehnya. Sanksi pajak yang berat akan berdampak semakin tinggi tingkat kepatuhan wajib pajak. Dengan arah hubungan yang positif sehingga semakin tinggi sanksi yang dikenakan, Wajib Pajak akan semakin patuh. (Zain, 2008:90). Sanksi Pajak juga diharapkan akan menimbulkan efek jera bagi Wajib Pajak yang sebelumnya sudah melakukan "ketidakpatuhan" dalam melaksanakan kewajiban perpajakannya.

\section{Sistem Samsat Dhrive Thru}

Samsat Drive Thru merupakan layanan samsat dimana WP tidak perlu turun dari kendaraan untuk mengantri membayar Pajak Kendaraan Bermotor dan lebih menghemat waktu. Unit Samsat Drive Thru merupakan unit pelayanan secara bersama dari 3 (tiga) instansi, yaitu terdiri dari unsur pelaksana Direktorat Lalu Lintas Polda Metropolitan Jakarta Raya, Dinas Pendapatan Daerah Provinsi DKI Jakarta dan PT. Jasa Raharja (Persero) Cabang DKI Jakarta, dengan susunan organisasi sebagai untuk penanggung jawab pelaksanaan tugas sehari-hari unit Samsat Drive Thru ditunjuk personel/pejabat dari masing-masing unsur instansi terkait selaku penanggung jawab pelaksana harian, sebagai berikut : 1) Kasubsi Samsat Jakarta Selatan. 2) Ka Unit Pajak Samsat Jakarta Selatan. 3) Penanggung Jawab PT Jasa Raharja (Persero) pada Samsat Jakarta Selatan. Dalam pelaksanaan tugasnya sehari-hari masing-masing penanggung jawab pelaksana harian Unit Samsat Drive Thru dikoordinasikan oleh Kepala Seksi STNK Subdit Regident Dit Lantas Polda Metropolitan Jakarta Raya, selanjutnya pertanggungjawaban secara berjenjang dilaksanakan sesuai prosedur dan ketentuan yang ada (Mawardi, 2011).

Dengan adanya Samsat Drive Thru diharapkan semakin banyak masyarakat yang antusias dalam menunaikan kewajibannya perpajakannya karena tanpa menunggu waktu yang lama dan pelayanan diberikan dengan mudah, singkat, aman, dan nyaman. 


\section{Pengembangan Hipotesis}

Kerangka berfikir menurut Sugiyono (2016: 60) adalah "model konseptual tentang bagaimana teori berhubungan dengan berbagai faktor yang telah diidentifikasi sebagai masalah yang penting". Perlu dijelaskan bahwa secara teoritis hubungan antar variabel independen dan dependen yang diteliti kemudian dipertautkan adalah kerangka berfikir yang baik. Setiap melakukan penyusunan paradigma penelitian harus berdasarkan pada kerangka berfikir yang telah ditetapkan.

\section{Pengaruh Pengetahuan Wajib Pajak Terhadap Kepatuhan Wajib Pajak Pajak Kendaraan Bermotor}

Pengetahuan perpajakan menurut Rahayu (2010: 141) "digunakan oleh wajib pajak sebagai informasi pajak dalam melakukan tindakan pajak seperti menghitung, memperhitungkan, membayar dan melaporkan jumlah pajak yang disetorkan". Semakin berkualitas pengetahuan yang dimiliki oleh masyarakat akan kewajiban perpajakan, akan berdampak pada pemenuhan kewajiban dengan sebaik-baiknya dan tepat waktu dengan dasar keadilan. Sehingga dapat dikatakan bahwa Pengetahuan wajib pajak berpengaruh terhadap kepatuhan dan ketidakpatuhannya dalam menjalankan kewajiban perpajakan dan berdampak pada penerimaan pajak negara.

Melalui uraian di atas, dalam kaitannya dengan Pajak Kendaraan Bermotor dapat dikatakan bahwa pengetahuan perpajakan diharapkan dapat membantu Wajib Pajak untuk patuh dalam membayar pajak kendaraan bermotornya, sehingga tingkat kepatuhan akan meningkat. Penelitian terdahulu yang dilakukan oleh Ilhamsyah dkk., (2016) dan juga penelitian yang lakukan Ihsan pada tahun 2013 memperlihatkan bahwa variabel pengetahuan wajib pajak memberikan pengaruh yang signifikan terhadap variabel kepatuhan wajib pajak. Perumusan akan hipotesisnya sebagai berikut :

\section{H1: "Pengetahuan Wajib Pajak berpengaruh positif terhadap Kepatuhan Wajib Pajak Kendaraan Bermotor".}

\section{Pengaruh Kesadaraan Wajib Pajak Terhadap Kepatuhan Wajib Pajak Pajak Kendaraan Bermotor}

Kesadaran wajib pajak menurut Irianto (2005: 50) "berpengaruh positif terhadap kepatuhan wajib pajak", mengandung arti "semakin tinggi kesadaran pajak yang dimiliki wajib pajak maka akan mengerti fungsi dan manfaat pajak", baik mengerti untuk diri sendiri maupun masyarakat, dari sini wajib pajak secara sukarela tanpa paksaan oleh siapapun akan membayar pajak. Wajib Pajak yang sadar akan kewajiban perpajakannya diharapkan akan meningkatkan angka kepatuhan wajib pajak.

Kesadaran wajib pajak adalah itikad baik yang dilakukan seseorang atau kelompok untuk melakukan pemenuhan kewajiban membayar pajak secara tulus ikhlas berdasarkan hati nuraninya. Penelitian yang sudah dilakukan oleh Susilawati dan Budiartha (2013) dan juga dilakukan oleh Ilhamsyah dan kawankawan pada tahun 2016 menunjukan pengaruh yang signifikan ditunjukkan oleh kesadaran wajib pajak terhadap kepatuhan wajib pajak. Dari uraian yang 
dilakukan oleh penelitian sebelumnya, menghasilkan rumusan hipotesis sebagai berikut:

H2: "Kesadaran Wajib Pajak berpengaruh Positif terhadap Kepatuhan Wajib Pajak Kendaraan Bermotor".

Pengaruh Sanksi Pajak Kendaraan Bermotor Terhadap Kepatuhan Wajib Pajak Pajak Kendaraan Bermotor

Sanksi tegas yang diterapkan terhadap wajib pajak, akan membuat wajib pajak membuat laporan sesuai dengan pendapatan yang diperolehnya. "Semakin berat sanksi yang ditetapkan, maka tingkat kepatuhan wajib pajak akan semakin tinggi". Arah hubungan yang positif artinya semakin tinggi atau berat sanksi yang dikenakan, maka wajib pajak akan semakin patuh. Sanksi di sini berperan untuk memberikan hukuman positif terhadap kelalaian akan kewajiban perpajakan dan efek jera akan dirasakan oleh wajib pajak setelah diberikan sanksi akan kelalaian yang dilakukan dan mau wajib pajak diharapkan dapat belajar dari kelalaian yang telah diperbuat sehingga, untuk pemenuhan kewajiban perpajakannya di masa pajak selanjutnya menjadi lebih patuh.

Sanksi perpajakan dalam penelitian yang dilakukan oleh Ilhamsyah dan kawan kawan menunjukkan adanya "pengaruh yang signifikan terhadap kepatuhan wajib pajak kendaraan bermotor". Dari uraian yang telah dikemukakan, maka hipotesis yang dapat diambil adalah sebagai berikut:

H3: "Sanksi Pajak Kendaraan Bermotor berpengaruh positif terhadap Kepatuhan Wajib Pajak Kendaraan Bermotor”.

Pengaruh Sistem Samsat Drive Thru Terhadap Kepatuhan Wajib Pajak Pajak Kendaraan Bermotor

Program drive thru menurut Mawardi (2011) merupakan "suatu inovasi yang baik dalam meningkatkan pelayanan terhadap wajib pajak, dalam eksposenya bertujuan untuk memudahkan masyarakat dalam bentuk pelayanan yang mudah, tepat, cepat, dan murah dalam rangka pembayaran pajak kendaraan yang setiap tahun dilakukan oleh setiap pemilik kendaraan bermotor". Dengan program tersebut, masyarakat tidak direpotkan untuk turun dari kendaraan yang dinaikinya, dan dalam hitungan menit urusan pajak atas kendaraannya yang sebelumnya sampai berjam-jam dalam pengurusannya, bisa selesai dengan cepat, lancer, dan mudah.

Penggunaan sistem samsat drive thru yang terus menerus, akan meningkatkan kepatuhan wajib pajak kendaraan bermotor. Efektifitas penerapan sistem samsat drive thru sudah terbukti pada penelitian Rahmawati pada tahun 2013. Hipotesis yang dapat dirumuskan berdasarkan uraian tersebut di atas adalah sebsagai berikut:

H4: "Sistem Samsat Drive Thru berpengaruh positif terhadap Kepatuhan Wajib Pajak Kendaraan Bermotor". 


\section{METODOLOGI PENELITIAN}

\section{Metode Pemilihan Sampel}

Populasi dalam penelitian yang dilakukan berjumlah 976.900 yaitu keseluruhan wajib pajak kendaraan bermotor roda empat yang sudah terdaftar di Samsat Drive Thru Jakarta Selatan. Sampel penelitian menurut Sugiyono (2012: 21) adalah "sebagian dari populasi yang diambil sebagai sumber data dan dapat mewakili seluruh populasi". Metode sampling yang digunakan adalah Teknik aksidental sampling yaitu "sebuah teknik penentuan jumlah sampel berdasarkan kebetulan", yaitu wajib pajak yang di temui oleh peneliti dalam proses penelitian yang secara kebetulan yang berada di Kantor Samsat Polda Metro jaya. Rumus Slovin digunakan unutk menentukan sampel. Dengan rumusan tersebut, besarnya sampel yang digunakan dalam penelitian ini sebesar 99,989 responden atau jika dibulatkan menjadi 100 responden.

Teknik sampling yang digunkanan dalam penelitian ini adalah “nonprobability sampling”. Sugiyono (2014:120) berpendapat bahwa Teknik nonprobability sampling adalah "sebuah teknik pengambilan sampel yang tidak memberikan peluang atau kesempatan sama bagi setiap unsur atau anggota populasi untuk dipilih menjadi sampel penelitian". Teknik nonprobability sampling terdiri atas "sampling sistematis, sampling kuota, sampling aksidental, purposive sampling, sampling jenuh dan snowball sampling”. Dalam penelitian ini teknik sampling yang dipakai oleh peneliti adalah teknik aksidental sampling, yaitu wajib pajak yang dalam penelitian di temui oleh peneliti yang secara kebetulan dalam satu bulan bertemu digunakan sebagai sampel penelitian, dijadikan sumber data jika dipandang cocok menurut peneliti.

\section{Pengumpulan Data}

Library Research atau penelitian kepustakaan, Online Research atau penelitian melalui internet, dan Field Research atau penelitian lapangan, digunakan sebagai teknik pengumpulan data. Tahapan Library Research dilakukan untuk memperoleh berbagai informasi yang nantinyanya akan dijadikan bahan dasar secara teori untuk membantu mengolah data dan sebagai bahan acuan dalam menyempurnakan pengolahan data, cara penggunaan penelitian kepusataakn dengan cara membaca kepustakaan yang sesuai, kemudian mempelajarinya, dilanjutkan dengan menelaah dan terakhir mengkaji literaturliteratur yang di dalamanya berupa buku-buku atau makalah atau jurnal atau penelitian-penelitian sebelumnya sudah dilakukan tetapi sesuai dengan variabel yang sedang diteliti sekarang. Peneliti juga mempelajari, menelaah, dan dilanjutkan dengan pengumpulan data-data primer yang berhubungan dengan objek penelitian. Tahapan Online Research atau penelitian melalui internet juga digunakan untuk mencari situs-situs yang berhubungan dengan penelitian guna memperoleh berbagai data yang dibutuhkan untuk menunjang kebutuhan penelitian. Tahapan Field Research atau penelitian lapangan digunkan untuk mengumpulkan data secara lengkap di lokasi objek penelitian yaitu Samsat Polda 
Metro Jaya Jakarta Selatan, dengan menggunakan metode observasi lapangan dan juga metode penyebaran angket/kuesioner.

\section{Teknik Analisis Data}

Analisis data yang dipakai dalam penelitian ini adalah "teknik analisis regresi berganda" guna pengolahan dan pembahasan data yang didapat, data tersebut untuk keperluan uji hipotesis. Pemilihan "teknik analisis regresi berganda" karena "teknik regresi berganda memberi kesimpulan bersifat langsung akan ada atau tidaknya pengaruh masing-masing variabel bebas yang digunakan secara parsial ataupun secara bersama-sama". Sugiyono (2014: 206) menyatakan "regresi berganda" adalah teknik statistik guna melihat keterkaitan hubungan antara variabel yang digunkana dalam penelitian, yaitu variabel terikat dengan beberapa variabel bebas yang telah ditetapkan.

Diperlukan data yang akurat dan dapat dipercaya untuk melakukan analisis data penelitian, karena hasilnya akan pergunakan dalam penelitian yang dilakukan. Program SPSS digunakan sebagi alat analisis data untuk meregresikan model yang telah dirumuskan.

\section{Analisis Deskriptif}

Statistik deskriptif digunakan untuk untuk "informasi yang diberikan mengenai karakteristik variabel penelitian yang utama dan daftar demografi responden". Hal ini digunakan untuk mendapatkan deskripsi atau gambaran atas data yang dilihat dari rata-rata (mean), Standar Deviasi, varian, maksimum, minimum (Imam Ghozali, 2016:19 Edisi 8). Jika data sudah terkumpul selanjutnya akan diuji dan dianalisis menggunakan SPSS 23.

\section{Uji Kualitas Data}

Data primer yang digunakan dalam penelitian ini diuji menggunakan dua uji kualitas data, yaitu " uji validitas dan uji reliabilitas".

\section{Uji Regresi Linear Berganda} adalah :

Persamaan Regresi yang dihasilkan dari Uji Regresi Linier Berganda ini

$\mathrm{Y}=\alpha+{ }_{\beta} 1 \mathrm{x} 1+{ }_{\beta} 2 \mathrm{x} 2+{ }_{\beta} 3 \times 3+{ }_{\beta} 4 \mathrm{x} 4+\mathrm{e}$

\section{Dimana :}

$\mathrm{Y} \quad=$ "Kepatuhan Wajib Pajak Kendaraan Bermotor"

$\mathrm{a} \quad=$ "Konstanta"

$\mathrm{x} 1=$ "Pengetahuan Wajib Pajak"

$\mathrm{x} 2=$ "Kesadaran Wajib Pajak"

x3 = "Sanksi Pajak Kendaraan Bermotor"

$\mathrm{x} 4=$ "Sistem Samsat Drive Thru"

e = "Eror" 


\section{HASIL DAN ANALISIS DATA}

\section{Statistik Deskriptif}

Hasil dari statistik deskriftif atas jawaban yang diberikan oleh responden disajikan pada tabel 4.1:

Tabel 4.1 Hasil Uji Statistik Deskriftif

\begin{tabular}{lr|r|r|r|r} 
& $\begin{array}{c}\text { N } \\
\text { Statistic }\end{array}$ & $\begin{array}{c}\text { Minimum } \\
\text { Statistic }\end{array}$ & $\begin{array}{c}\text { Maximum } \\
\text { Statistic }\end{array}$ & $\begin{array}{c}\text { Mean } \\
\text { Statistic }\end{array}$ & $\begin{array}{c}\text { Std. Deviation } \\
\text { Statistic }\end{array}$ \\
\hline Pengetahuan Wajib Pajak & 100 & 12 & 20 & 15,87 & 2,058 \\
\hline Kesadaran Wajib Pajak & 100 & 12 & 20 & 15,26 & 1,790 \\
\hline Sanksi Pajak Kendaraan Bermotor & 100 & 12 & 20 & 15,46 & 1,806 \\
\hline Sistem Samsat Drive Thru & 100 & 12 & 30 & 19,44 & 2,757 \\
\hline Kepatuhan Wajib Pajak PKB & 100 & 13 & 20 & 15,39 & 1,340 \\
\hline Valid N (listwise) & 100 & & & &
\end{tabular}

Sumber: Data yang di olah SPSS 24,00

Tabel 4.1 menunjukkan adanya variabel $\mathrm{X} 1$ yaitu pengetahuan wajib pajak dengan besaran jawaban minimum dari responden adalah 12 dan besaran maksimum adalah 20, dengan rmean atau rata-rata 15,87 dan standar deviasinya sebesar 2,058, variabel X2 yaitu kesadaran wajib pajak dengan besaran jawaban minimum dari responden adalah 12 dan besaran jawaban maksimum adalah 20, dengan mean atau rata-rata 15,26 dan standar deviasinya 1,790, variabel X3 yaitu sanksi pajak kendaraan bermotor dengan besaran jawaban minimum dari responden adalah 12 dan besaran jawaban maksimum adalah 20, dengan mean atau rata-rata 15,46 dan standar deviasinya adalah 1,806 , variabel X4 yaitu variabel sistem samsat drive thru dengan besaran jawaban minimum dari responden adalah 12 dan besaran jawaban maksimum adalah 30, dengan mean atau rata-rata 19,44 dan standar deviasinya adalah 2,757, pada variabel kepatuhan wajib pajak kendaraan bermotor dengan besaran jawaban minimum dari responden adalah 12 dan besaran jawaban maksimum dari responden adalah 20, dengan mean atau rata-rata 15,39 dan standar deviasinya adalah 1,340.

\section{Diskusi Hasil}

Untuk mendiskusikan hasil penelitian, maka akan digunakan "analisis regresi linear berganda”. Model regresi linear berganda yang digunakan dalam penelitian ini disajikan dalam persamaan sebagai berikut: 
Tabel 4.2 Hasil Uji Regresi Linear Berganda

\begin{tabular}{|c|c|c|c|c|}
\hline \multirow{2}{*}{\multicolumn{2}{|c|}{ Model }} & \multicolumn{2}{|c|}{ Unstandardized Coefficients } & \multirow{2}{*}{$\begin{array}{c}\text { Standardized } \\
\text { Coefficients } \\
\text { Beta }\end{array}$} \\
\hline & & B & Std. Error & \\
\hline \multirow[t]{5}{*}{1} & (Constant) & 12,992 & 2,041 & \\
\hline & Pengetahuan WP & ,131 & ,063 & ,201 \\
\hline & Kesadaran WP & , 159 & ,071 & ,212 \\
\hline & Sanksi PKB & ,014 & ,072 & ,018 \\
\hline & Sistem samsat drive &,- 119 & ,046 &,- 245 \\
\hline
\end{tabular}

.a. Dependent Variable: kepatuhan wajib pajak kendaraan bermotor

Sumber: Data Primer diolah dengan SPSS 24,00

Persamaan regresi linear berganda sebagai berikut :

$\mathrm{Y}=12,992+0,131+0,159+0,014+(-119)=2,041$

1. Konstanta sebesar 12,992 artinya menyatakan bahwa tanpa adanya variabel $\mathrm{X} 1$, variabel $\mathrm{X} 2$, variabel $\mathrm{X} 3$, dan variabel $\mathrm{X} 4$ maka variabel $\mathrm{Y}$ yaitu kepatuhan wajib pajak pajak kendaraan bermotor tetap terbentuk 12,992.

2. Koefisien regresi variabel X1 (pengetahuan wajib pajak) positif pengaruhnya terhadap variabel Y dengan menunjukkan nilai koefisien sebesar 0.131 yang berarti variabel X1 (Pengetahuan Wajib Pajak) meningkat satu satuan dengan asumsi klasik X2, X3, X4 nilai tetap maka Y meningkat dengan besaran sebesar 0,131.

3. Koefisien regresi variabel $\mathrm{X}_{2}$ (kesadaran wajib pajak) positif pengaruhnya terhadap variabel $\mathrm{Y}$ dengan menunjukkan "nilai koefisien" sebesar 0.159 yang artinya jika variabel $\mathrm{X}_{2}$ (kesadaran Wajib Pajak) meningkat satu satuan dengan asumsi klasik $\mathrm{X}_{2}, \mathrm{X}_{3}, \mathrm{X}_{4}$ nilai tetap maka $\mathrm{Y}$ meningkat dengan besaran sebesar 0,159.

4. Koefisien regresi variabel $\mathrm{X}_{3}$ (sanksi pajak kendaraan bermotor) positif pengaruhnya terhadap Y dengan menunjukkan nilai koefisien sebesar 0.014 yang berarti variabel $\mathrm{X}_{3}$ (sanksi pajak kendaraan bermotor) meningkat satu satuan dengan asumsi klasik X2, X3, X4 nilai tetap maka Y meningkat dengan besaran sebesar 0,014.

5. Koefisien regresi variabel $\mathrm{X}_{4}$ (sistem samsat drive thru) positif pengaruhnya terhadap Y dengan menunjukkan nilai koefisien sebesar 0.119 yang berarti jika variabel $\mathrm{X} 4$ (sistem samsat drive thru) meningkat satu satuan dengan asumsi klasik $\mathrm{X}_{2}, \mathrm{X}_{3}, \mathrm{X}_{4}$ nilai tetap maka $\mathrm{Y}$ meningkat dengan besaran sebesar 0,119.

Koefisien korelasi diterapkan untuk mencari tahu hubungan yang ada antar variabel, yaitu antar variabel independen dan variabel dependen. Kegunaan koefisien korelasi untuk mencari tahu seberapa kuatkah hubungan antar variabel dependen terhadap variabel independen. Untuk meningkatkan kembali nilau korelasi antara kedua variabel - sampai dengan $1=$. Dimana $r$ dapat bervariasi, dimana $\mathrm{r}=0$ atau mendekati 0 , maka hubungan antara variabel tersebut dikatakan 
lemah. Bila $r=1$ atau mend ekati 1 . Maka hubungan tersebut dikatakan kuat. Berikut adalah hasil uji koefisien korelasi

Selanjutnya adalah Uji statistik t, uji ini diberlakukan "untuk mengetahui besaran pengaruh tiap variabel $X$ secara individual dalam menerangkan variasi variabel Y". Jika yang didapat probabilitas lebih kecil dari 0,05 maka dapat disimpulkan jika hasilnya memberikan pengaruh yang signifikan dari variabel $\mathrm{X}$ (variabel bebas/independen) terhadap variabel Y (variabel terikat/dependen).

Tabel 4.3 Hasil Uji Statistik t (Parsial)

\begin{tabular}{|c|c|c|c|c|c|c|}
\hline \multirow[b]{2}{*}{ Model } & & \multicolumn{2}{|c|}{ Unstandardized Coefficients } & \multirow{2}{*}{$\begin{array}{c}\text { Standardized } \\
\text { Coefficients } \\
\text { Beta }\end{array}$} & \multirow[b]{2}{*}{$\mathrm{T}$} & \multirow[b]{2}{*}{ Sig. } \\
\hline & & $\mathrm{B}$ & Std. Error & & & \\
\hline 1 & (Constant) & 12,992 & 2,041 & & 6,364 & ,000 \\
\hline & Pengetahuan WP & ,131 & 063 & ,201. & 2,068 & 041 \\
\hline & Kesadaran WP & , 159 & ,071 & ,212 & 2,249 &, 027 \\
\hline & Sanksi PKB & 014 & ,072 &, 018 & , 188 & 851 \\
\hline & $\begin{array}{l}\text { Sistem Samsat } \\
\text { Drive Thru }\end{array}$ &,- 119 & ,046 &,- 245 & $-2,590$ & 011 \\
\hline
\end{tabular}

Sumber: Data Primer diolah SPSS 24,00

Penentuan distribusi t selanjutnya dicari pada $=10 \%: 2=5 \%$ (uji 2 sisi) dengan derajat kebebasan dimana $(\mathrm{df})=100-4=96$. Degan pengujian dua sisi signifikansi $=5 \%$ maka $\mathrm{t}$ tabel yang digunakan 1,661 .

Pada tabel 4.22 menujukkan hasil uji hipotesis 1 di mana variabel $\mathrm{X}_{1}$ yaitu pengetahuan wajib pajak menunjukkan bahwa tingkat signifikansi variabel $\mathrm{X}_{1}$ terhadap Variabel Y yaitu kepatuhan wajib pajak kendaraan bermotor 0,041 < 0,05 dan $\mathrm{t}$ hitung $>\mathrm{t}$ tabel $(2,068>1,661)$ sehingga dapat disimpulkan bahwa "Variable $\mathrm{X}_{1}$ memberikan pengaruh yang signifikan terhadap variabel $\mathrm{Y}$ ". Sehingga hipotesis $1\left(\mathrm{H}_{1}\right)$ diterima.

Dari hasil uji hipotesis tersebut di atas sejalan dengan apa yang sudah diteliti oleh Muchsin Ihsan (2013), dengan hasil variabel $X_{1}$ dalam penelitian ini, yaitu "pengetahuan wajib pajak berpengaruh signifikan terhadap Variabel Y yaitu kepatuhan wajib pajak badan".

Hasil uji hipotesis 2 Tabel 4.3 variabel kesadaran wajib pajak selaku variabel $\mathrm{X}_{2}$ menunjukkan bahwa tingkat signifikansi variabel $\mathrm{X}_{2}$ terhadap kepatuhan wajib pajak kendaraan bermotor selaku variabel Y 0,027 $<0,05$ dan $t$ hitung $(2,249>1,661)$ sehingga dapat disimpulkan bahwa "variabel $\mathrm{X}_{2}$ berpengaruh signifikan terhadap variabel Y". Sehingga Hipotesis $2\left(\mathrm{H}_{2}\right)$ Diterima.

Dari hasil uji hipotesis tersebut di atas, sejalan dengan apa yang sudah diteliti oleh Ilhamsyah dkk (2016), di mana hasilnya menyatakan bahwa "kesadaran wajib pajak selaku variabel $\mathrm{X}_{2}$ dalam penelitian ini, mempunyai 
pengaruh yang signifikan terhadap variabel $\mathrm{Y}$ yaitu kepatuhan wajib pajak kendaran bermotor".

Hasil Uji Hipotesis 3 Tabel 4.3 variabel sanksi pajak kendaraan bermotor menunjukkan bahwa tingkat signifikansi variabel sanksi pajak kendaraan bermotor terhadap kepatuhan wajib pajak $0,851>0,05$ dan t hitung $(0,188<$ $1,661)$ sehingga dapat disimpulkan bahwa "sanksi pajak kendaraan bermotor tidak berpengaruh secara signifikan terhadap kepatuhan wajib pajak kendaraan bermotor". sehingga hipotesis $3 \mathrm{H}_{0}$ diterima $\mathrm{H}_{3}$ ditolak.

Hasil uji hipotesis yang ada, sejalan dengan apa yang sudah diteliti ole Irianingsih (2015) yang menyatakan bahwa "sanksi pajak kendaraan bermotor tidak berpengaruh secara signifikan terhadap kepatuhan wajib pajak kendaraan bermotor".

Hasil Uji Hipotesis 4 Tabel 4.3 variabel sistem samsat drive thru menunjukkan bahwa "tingkat signifikansi variabel sistem samsat drive thru terhadap kepatuhan wajib pajak kendaraan bermotor 0,011<0,05 dan thitung $>\mathrm{t}$ tabel $(2,590>1,661)$ " , kesimpulannya adalah: "sistem samsat drive thru berpengaruh secara signifikan terhadap kepatuhan wajib pajak kendaraan bermotor". Sehingga hipotesis $\left(\mathrm{H}_{4}\right)$ Diterima.

Hasil yang di dapat penelitian ini seperti penelitian Rahmawati (2013) yang menyatakan bahwa "sistem samsat drive thru memberikan pengaruh yang signifikan terhadap kepatuhan wajib pajak kendaraan bermotor".

Hasil uji statistik $\mathrm{F}$ bisa dillihat dari nilai probabilitas yang mempunyai nilai lebih kecil dari 0,05 , dari sini model regresi selanjutnya digunakan dalam memprediksi 4 (empat) variabel dependen yang digunakan. Hasil uji statistik F disajikan sebagai berikut:

Tabel 4.4 Hasil Uji F (Simultan)

\begin{tabular}{|l|r|r|r|r|r|}
\hline Model & $\begin{array}{l}\text { Sum of } \\
\text { Squares }\end{array}$ & Df & Mean Square & F & Sig. \\
\hline Regression & 30,939 & 4 & 7,735 & 5,004 &, $001^{\text {b }}$ \\
\hline Residual & 146,851 & 95 & 1,546 & & \\
\hline Total & 177,790 & 99 & & & \\
\hline
\end{tabular}

a. Dependent Variable: $y$

b. Predictors: (Constant), x4, x3, x2, x1

Sumber: Data Primer di olah SPSS 24,00

Dari tabel 4.4 dapat diketahui nilai $\mathrm{F}$ hitung sebesar 5,004 sedangkan $\mathrm{F}$ tabel pada $=0,05$ dengan derajat kebebasan pembilang $=(\mathrm{k}-1)=4-1$, dengan derajat penyebut $=(n-4)=100-4=96$ dengan $\mathrm{t}$ tabel 2,47 maka, $\mathrm{F}$ hitung 5,004 $>\mathrm{F}$ tabel 2,47. Nilai signifikansi hasil uji $\mathrm{F}$ sebesar $0,001<$ dari 0,05 , dapat disimpulkan bahwa "pengetahuan wajib pajak selaku variabel $X_{1}$, kesadaran wajib pajak selaku variabel $\mathrm{X}_{2}$, sanksi pajak kendaraan bermotor selaku variabel $\mathrm{X}_{3}$ dan sistem samsat drive thru selaku variabel $\mathrm{X}_{4}$ berpengaruh terhadap variabel $\mathrm{Y}$ yaitu kepatuhan wajib pajak kendaraan bermotor". Artinya dalam regresi ini variabel independen dapat mendeteksi pengaruh variabel dependen terhadap variabel independen. 


\section{KESIMPULAN DAN SARAN}

\section{Kesimpulan}

Dari penelitian yang sudah dilakukan di atas, melalui prosedur yang telah dilakukan sesuai dengan kebutuhan penelitian dan keseusaian variabel penelitian yang digunakan, kesimpulannya adalah:

1. Terdapat "pengaruh positif dan signifikan" antara pengetahuan wajib pajak terhadap kepatuhan wajib pajak kendaraan bermotor. Hal ini menunjukkan bahwa wajib pajak mempunyai pengetahuan tentang pajak yang tinggi dan cenderung taat akan kewajiban perpajakannya.

2. Terdapat "pengaruh positif dan signifikan" antara kesadaran wajib pajak terhadap kepatuhan wajib pajak kendaraan bermotor. Hal ini menunjukkan bahwa wajib pajak di Samsat Polda Metro Jaya Jakarta Selatan memiliki kesadaran pada dirinya yang sangat tinggi untuk menjalankan kewajibannya selaku wajib pajak.

3. Terdapat "pengaruh yang negatif dan tidak signifikan" pada variabel sanksi pajak kendaraan bermotor . Hal ini bahwa seseorang wajib pajak mengetahui sanksi apa yang akan diberikan tetapi masih tetap saja mengabaikan kewajibannya sebagai wajib pajak.

4. Terdapat "pengaruh positif dan signifikan antara sistem samsat drive thru terhadap kepatuhan wajib pajak kendaraan bermotor". Berarti sistem samsat drive thru lebih memudahkan wajib pajak untuk membayar pajak kendaraan bermotornya tanpa harus mengantri di loket samsat Polda Metro Jaya.

5. Terdapat pengaruh positif dan signifikan dari variabel "pengetahuan wajib pajak, kesadaran wajib pajak, sanksi pajak kendaraan bermotor dan sistem samsat drive thru terhadap kepatuhan wajib pajak kendarana bermotor".

\section{Saran}

Melihat hasil dari penelitian yang ada, saran ke depannya adalah sebagai berikut :

1. Peneliti berikutnya diharapkan dapat menjabarkan lebih luas obyek dari penelitian sekarang, misalnya mengambil sampel di samsat terkhusus samsat drive yang berada di beberapa kabupaten, sehingga gambaran akan lebih jelas dan akan memaksimalkan hasilnya.

2. Dalam penelitian selanjutnya, Peneliti diharapkan melakukan pendampingan secara personal terhadap responden dalam mengisi kuesioner yang diberikan oleh peneliti, dengan ini harapannya adalah wajib pajak yang ditemui bisa mengerti dankuesioner yang diberikan dapat dipahami atas pernyataan yang disajikan.

3. Lima variabel dependen yang digunakan dalam penelitian yang sekarang dilakukan, diharapkan dapat ditambah lagi dependen variabelnya oleh peneliti berikutnya, kenapa ? akan semakin luas kemungkinan ada variabel lain yang memberikan pengaruh terhadap variabel independen yang sudah ada sekarang. 
4. Bagi Samsat Drive Thru Polda Metro Jaya diharapkan sering mengadakan sosialisasi perpajakan sehingga wajib pajak mendapat pengarahan atau pengetahuan yang lebih untuk meningkatkan kepatuhan wajib pajak yang lebih maksimal.

5. Penelitian selanjutnya dpat meneliti obyek penelitian, misalnya variavel yang diambil berpngaruh secara signifikan dan positif semua.

\section{DAFTAR PUSTAKA}

Andri, Irianto. (2005). Panduan Pengembangan Organisasi. Penerbit Andi. Yogyakarta

Anggara, Sahya. Dr. (2016). Hukum Administrasi Perpajakan. Penerbit Pustaka Setia Bandung.

Carolina, Veronica. (2009). Pengetahuan Pajak. Jakarta: Salemba Empat.

Direktorat Jenderal Pajak Kanwil DJP Jakarta Selatan. (2011) . Buku Panduan Hak dan Kewajiban Wajib Pajak.

Ghozali, Imam. (2016). Aplikasi Analisis Multivariate Dengan Program SPSS IBM 23. Semarang: Badan Penerbit Universitas Diponegoro.

Ihsan, Muchsin. (2013). Pengaruh Pengetahuan Wajib Pajak, Penyuluhan Pajak, Kualitas Pelayanan Pajak, Dan Pemeriksaan Pajak Terhadap Kepatuhan Wajib Pajak Badan Di Kota Padang. Fakultas Ekonomi Universitas Negeri Padang.

Ilhamsyah, Randi, Maria G Wi Endang dan Rizky Yudhi Dewantara. (2016). Pengaruh Pemahaman dan Pengetahuan Wajib Pajak Tentang Peraturan Perpajakan, Kesadaran Wajib Pajak, Kualitas Pelayanan, dan Sanksi Perpajakan Terhadap Kepatuhan Wajib Pajak Kendaraan Bermotor (Studi Samsat Kota Malang). Jurnal Perpajakan (JEJAK)| Vol. 8 No. 1

Irianingsih, Eka. (2015). Pengaruh Kesadaran Wajib Pajak, Pelayanan Fiskus dan Sanksi Administrasi Pajak Terhadap Kepatuhan Wajib Pajak Dalam Membayar Pajak Kendaraan Bermotor (PKB) Kantor Pelayanan Pajak Kendaraan Bermotor SAMSAT Sleman.

Kemala, Winda. (2015). Pengaruh Kesadaran Wajib Pajak, Pengetahuan Pajak, Sikap Wajib Pajak dan Reformasi Administrasi Perpajakan Terhadap Kepatuhan Wajib Pajak Kendaraan Bermotor. JOM. FEKOM Vol. 2 No. 1 Februari 2015

Lubis, Arfan Ikhsan. (2010). Akuntansi Keprilakuan. Penerbit Salemba Empat. Jakarta

Mardiasmo. (2016). Perpajakan Edisi Terbaru. Penerbit Andi . Yogyakarta .

Mawardi, Leganek. (2011). Optimalisasi Samsat Drive Thru Guna Mewujudkan Pelayanan Prima Dalam Rangka Mendukung Transparasi Pelayanan Polri Pada Samsat Jakarta Selatan. Skripsi Universitas Indonesia. Jakarta

Mohammad, Zain. (2008). Manajemen Perpajakan Edisi 3. Penerbit Salemba Empat. Jakarta 
Moenir. H.A.S. (2011). Manajemen Pelayanan Umum di Indonesia. Penerbit Bumi Aksara. Jakarta

Nurlaela, Siti. (2013). Pengaruh Pengetahuan dan Pemahaman, Kesadaran, Persepsi terhadap Kemauan Membayar Pajak Wajib Pajak Orang Pribadi yang Melakukan Pekerjaan Bebas. Jurnal Paradigma Vol. 11 No. 02.

Nurmanto, Safri. (2007). Pengantar Perpajakan. Penerbit Yayasan Obor Indonesia

Pranata, Teuku Andre. Mukhlizul Hamdi, Herawati. (2015). Pengaruh Kesadaran Wajib PAJAK, Sanksi Denda Pajak dan Kualitas Pelayanan Pajak Terhadap Kepatuhan Wajib Pajak Dalam Membayar Pajak Kendaraan Bermotor Di Bukit Tinggi.

Rahayu, Siti Kurnia. (2010). Perpajakan Indonesia. Penerbit Graha Ilmu. Jakarta Rahmawati, Novia. (2013). Analisis Efektifitas Pemungutan Pajak Melalui Layanan Samsat Drive Thru (Studi Kasus Kantor Bersama Samsat Batu Kota). Fakultas Ekonomi dan Bisnis Universitas Brawijaya Malang.

Resmi, Siti. (2015). Perpajakan Teori dan Kasus . Penerbit Salemba Empat. Jakarta

Robbins, Stephen P. (2008). Perilaku Organisasi. Penerbit Prenhallindo. Jakarta

Saragih, Nurzannah. (2016) . Pengaruh Pemahaman Peraturan Pajak Terhadap Kepatuhan Wajib Pajak Dengan Preferensi Risiko Sebagai Variabel Moderating. Universitas Pamulang.

Sari, Diana. (2013). Konsep Dasar Perpajakan. Penerbit Refika Aditama. Jakarta

Siahaan, Marihot P. (2013). Pajak Daerah dan Retribusi Daerah, Jakarta : Raja Grafindo

Sugiyono. (2016). Metode Penelitian Kuantitatif, Kualitatif dan R\&D. Penerbit Alfabeta.

Susilawati, Ketut Evi dan Ketut Budiartha. (2013). Pengaruh Kesadaran Wajib Pajak, Pengetahuan Pajak, Sanksi Perpajakan, dan Akuntabilitas Pelayanan Publik pada Kepatuhan Wajib Pajak Kendaraan Bermotor. EJurnal Akuntansi Universitas Udayana Vol 4 No.2 (2013): 345-357

Ummah, Muslikhatul. (2015). Pengaruh Kesadaran Wajib Pajak, Sanksi Pajak, Pengetahuan Perpajakan Dan Pelayanan Fiskus Terhadap Kepatuhan Wajib Pajak Kendaraan Bermotor Di Kabupaten Semarang. Fakultas Ekonomi Universitas Dian Nuswantoro.

Waluyo. (2017). Perpajakan Indonesia Edisi 12 Buku 1. Penerbit Salemba Empat.

Wardani, Dewi Kusuma. Rumiyatun. (2017). Pengaruh Pengetahuan Wajib Pajak, Kesadaran Wajib Pajak, Sanksi Pajak Kendaraan Bermotor dan Sistem Samsat Drive Thru Terhadap Kepatuhan Wajib Pajak Kendaraan Bermotor (Studi Kasus WP PKB roda Empat di samsat Drive Thru Bantul). Universitas Sarjawawiyata Tamansiswa Yogyakarta.

Widodo, Widi, Dkk . (2010). Moralitas, Budaya dan Kepatuhan Pajak. Penerbit Alfabeta Bandung.

Zuraida, Ida. (2013). Teknik Penyusunan Peraturan Daerah. Penerbit Sinar Gratika Jakarta. 